Teknomekanik

Vol.4, No.2, Dec 2021, pp. 55 63

e-ISSN: 2621-8720 p-ISSN: 2621-9980

\title{
Performance Comparison of Ground Source Heat Pump (GSHP) against Air Source Heat Pump (ASHP) for Domestic Applications: A case study in Perth, Australia
}

\author{
Tine Aprianti ${ }^{1,2}$, Evan Tan ${ }^{3}$, Chan Diu³, Ben Sprivulis ${ }^{3}$, Greg Ryan ${ }^{4}$, Kandadai Srinivasan ${ }^{1}$, and \\ Hui Tong Chua ${ }^{1}$ \\ ${ }^{1}$ Department of Chemical Engineering, Faculty of Engineering, The University of Western Australia, Perth 6009, \\ Australia \\ ${ }^{2}$ Department of Chemical Engineering, Faculty of Engineering, Sriwijaya University, Ogan Ilir 30662, Indonesia \\ ${ }^{3}$ Department of Mechanical Engineering, Faculty of Engineering, The University of Western Australia, Perth 6009, \\ Australia \\ ${ }^{4}$ DevelopmentWA, Government of Western Australia, Perth 6009, Australia
}

\begin{tabular}{|c|c|}
\hline Article Info & ABSTRACT \\
\hline Article history: & The goal of this research is to evaluate the efficacy and practicality of \\
\hline Received Jun $14^{\text {th }}, 2021$ & air source heat pump \\
\hline Revised Aug $16^{\text {th }}, 2021$ & by monitoring each of the systems in two almost identical residences in Perth \\
\hline Accepted Oct $19^{\text {th }}, 2021$ & Western Australia. There is an open-loop groundwater system in the previous \\
\hline Keywords: & $\begin{array}{l}\text { own set of operational needs. The cooling capacity supplied and coefficient of } \\
\text { performance (COP) as a function of seasonal changes in ambient }\end{array}$ \\
\hline Ground Source Heat $\mathrm{F}$ & temperatures were determined using data gathered from both residences over \\
\hline Air Source Heat Pump & a two-year period. For both heating and cooling, the GSHP system COP was \\
\hline Air Conditioning & found to be greater than that of the ASHP system. Furthermore, these two \\
\hline Geothermal Application & performance measures were independent of ambient circumstances in the \\
\hline Groundwater System & former, but they exhibit a noticeable ambient dependent trend in the latter. The \\
\hline & $\begin{array}{l}\text { GSHP had an average COP of } 4.0 \text { for heating, regardless of external } \\
\text { conditions, while the ASHP COP ranged from } 2.0 \text { to 3.0. Conversely, the } \\
\text { GSHP had an average COP of } 3.2 \text { for cooling, whereas the ASHP COP ranged } \\
\text { from } 1.4 \text { to 2.9. It is found that GSHPs result in significant operational cost } \\
\text { reductions and a significant decrease in greenhouse gas emissions when a } \\
\text { borewell is part of a home. }\end{array}$ \\
\hline
\end{tabular}

\section{Corresponding Author:}

Hui Tong Chua,

Departement of Chemical Engineering, Faculty of Engineering, The University of Western Australia, 35 Stirling Hwy, Perth 6009, Australia

Email: huitong.chua@uwa.edu.au

\section{INTRODUCTION}

Based on the Australian energy regulator [1], electricity markets in the twenty-first century exhibited a rising tendency to $210 \mathrm{TWh}$ until around 2008-9, and then a small decline to 195.7 town to date. However, the residential and commercial sectors accounted for around 13\% of total energy use [2]. Consumer reaction to rising power rates, the introduction of energy-efficient equipment, and smarter house design are all possible causes for the drop. This development might be interpreted as a sign of Australians' eagerness to implement more energy-efficient measures in their houses. The trend, no doubt, encourages Australians to consider alternate ways to heat and cool their houses, as heating and cooling may account for up to $40 \%$ of a household's energy usage [3]

Adoption of ground source heat pumps is one approach to minimize energy usage (GSHPs). GSHPs utilise the subterranean environment's consistent temperature as a heat source for heating and a heat sink for cooling, insulating heating and cooling equipment from diurnal and seasonal temperature changes [4]. This feature should be considered in conjunction with a reduction in the amount of energy required to operate GSHPs as well as making them more environmentally friendly [5]. The direct use of geothermal energy has been

Journal homepage: http://teknomekanik.ppj.unp.ac.id

DOI: https://doi.org/10.24036/teknomekanik.v4i2.11272 
widespread in a variety of industries globally [6] in general, and in Australia in particular, including the heating of swimming pools [7,8].

The usage of GSHPs for home heating and cooling is now on the rise [9], particularly in Australia. For example, in 2012, a project using GSHP systems was launched in Melbourne, with the goal of boosting the geothermal sector in the state [10]. In 2019, the Fairwater master-planned residential development in Blacktown, Western Sydney, installed a AUD 1.7 million commercial-scale demonstration of renewable ground-source heat pumps [11,12], this project [13] in Australia focuses on residential clusters for heating and cooling purposes. High capital costs, uncertainty about the ideal design, and poor customer confidence can all be deterrents to adopting this technology [14].

The design of various forms of GSHP requires a geological study [15]. Water quality and quantity must be examined beforehand, especially in open loop systems (as is the case in this study). There are two types of GSHP systems: open-loop and closed-loop systems [9]. GSHPs have been compared to traditional heating and cooling techniques in prior research. The GSHP's COP for cooling was found to be $32-54 \%$ greater than the ASHP's, while the augmentation for heating was 36-38\% [16]. The basic energy consumption of the heat pump system is $71 \%$ less than that of a reference installation based on conventional gas-fired boilers and water cooling machines, according to a study of an aquifer thermal storage system in a Belgian hospital [17]. The heat pump COP during the cooling phase is 6.0-10.9 at partial load, while the total system COP is 4.3-7.4, according to a research conducted at Pusan National University in Korea to evaluate the performance of a ground source heat pump (GSHP) system. The heat pump COP at partial load during the heating season is 4.38.3, whereas the entire system $C O P$ is 3.0-6.2. [18]. The closed-loop GSHP and variable refrigerant flow (VRF) systems installed in ASHRAE Headquarters in Atlanta were described by Southard et al. [19]. They observed a significant increase in heating COP of 4.6 for the GSHP system compared to 3.1 for the VRF system, and a significant increase in cooling $C O P$ of 3.3 from 2.1 for the VRF system. A study was carried out to see if high conductivity phase change material (PCM) could be used in the borehole heat exchanger of a GSHP to shorten the borehole length and increase the COP [20]. The maximum COP values of a GHSP computed assuming an ideal reversed Carnot cycle for cooling mode increased by about 81 percent with PCM and by 112 percent with graphite enhanced PCM, according to the results of its studies.

Molavi and McDaniel [21] conducted a comprehensive evaluation of GSHPs for retail buildings in the northeast of the United States and found that, while they all offer environmental advantages, a lack of understanding and risk assessment is preventing broad adoption. Self et al. [22] reviewed open-loop systems and validated their advantages over alternative configurations. In a school facility during the winter season 2008, Song et al. [23] compared GSHP with an ASHP. Their research discovered that ground temperatures at a shallow depth of 2 to $5 \mathrm{~m}$ are considerably impacted by outside temperatures, but ground temperatures at depths below $20 \mathrm{~m}$ remain constant at about $16^{\circ} \mathrm{C}$. According to this study, the GSHP has a COP of 5.1 for a heat pump and 4.2 for the whole system, which includes the work of the circulation pump. The total COP of the GSHP system is $31 \%$ greater than the ASHP system. The greater $C O P$ is attributed to a $10^{\circ} \mathrm{C}$ higher temperature at the evaporator for the GSHP system, resulting in a reduced pressure difference for the refrigerant compressor.

Michopoulos et al. [24] compared vertical GSHP to conventional systems in single and multi-family dwellings in numerous sites in Cyprus with varying climatic circumstances. These technologies were looked at for both heating and cooling purposes. In two typical residential structures in Cyprus, simulations were run to calculate the amount of power consumed by both GSHP and conventional systems. The findings reveal that the major energy savings for GSHP systems are significantly dependent on geography, with reductions of up to $33.6 \%$ in colder locations and $23.5 \%$ in warmer places. It has also been discovered that energy savings are greater in multi-family homes than in single-family homes.

The heating performance of three vertical closed-loop water-to-air GSHP systems built in three new single-family detached houses in Innisfail ( $80 \mathrm{~km}$ north of Toronto, Canada) was monitored, examined, and assessed throughout one heating season by Abdel-Salam et al. [25]. The findings demonstrate that GSHPs can fulfill peak heating demands without the need of an additional heating element. The COPs for the three seasons are 4.2, 4.0, and 3.4, respectively. The comparative results reveal that the sum of the running expenses of the GSHP system is roughly one third of the present heating and cooling systems in a refurbished campus building in Korea [26]. The influence of various system factors on GSHP performance is investigated using a computer model [27]. Based on a comparative economic evaluation that was performed to examine the feasibility of employing a GSHP in lieu of traditional heating/cooling systems and an ASHP, the conclusion suggests that GSHP is economically advantageous to conventional systems. The Solar Energy Institute at Ege University in Izmir, Turkey, on the other hand, investigated the cooling performance of a vertical GSHP system installed in a $65 \mathrm{~m}^{2}$ room [28]. Due to the oversizing of several system elements, the cooling coefficient of the GSHP performance and the entire system is relatively low when compared to other heat pumps operating under

Journal homepage: http://teknomekanik.ppj.unp.ac.id

DOI: https://doi.org/10.24036/teknomekanik.v4i2.11272 
conditions at or near design values. While there is no question that GSHPs offer significant environmental and operational benefits, the price of drilling, pumping, and piping, as well as their running costs and heat exchanger derating, have been stumbling blocks. In the residential sector, a holistic assessment is required, taking into consideration all aspects. Through a simulation on a typical house in Cyprus, Christodoulides et al. [29] addressed this characteristic and found that GSHPs were unlikely to be cost-effective due to payback times of the order of 20 years. Despite the GSHP's greater initial cost, the benefits of lower $\mathrm{CO}_{2}$ emissions and lower operating expenses may outweigh the disadvantages [30].

A study of the literature suggests that GSHPs may not be a viable alternative for household usage, owing to the high expense of drilling. When a borewell is included as part of a home's reticulation or water supply, however, such expenditures are practically eliminated for GSHP operations. This is the scenario in Perth and its environs, where there were 190,000 garden bores in 2017 [32]. In India, this is also the case in many metropolitan areas. Bangalore, for example, has 400,000 authorized borewells [33]. Heating and cooling are a need in all of those metropolitan communities. In addition, using water for GSHPs offers the advantage of using that valuable resource at a net zero level. There has been relatively little attempt to support a comparison of GSHP and ASHP in the residential sector through real measurements in this context. In Perth, two almost similar houses were built next to each other, one with a GSHP in open-loop mode and the other with a traditional ASHP, to cover this gap. A comparison of the two systems' performance is based on real-world data collected over more than two years and across all seasons. It has been demonstrated that there is a significant direct saving of energy and related expenses, as well as environmental advantages as a corollary.

\section{METHODS}

The physical systems consist of two almost similar neighboring single-story residential houses with frontal views as shown in Figure 1, constructed in 2016 in Perth, Australia.

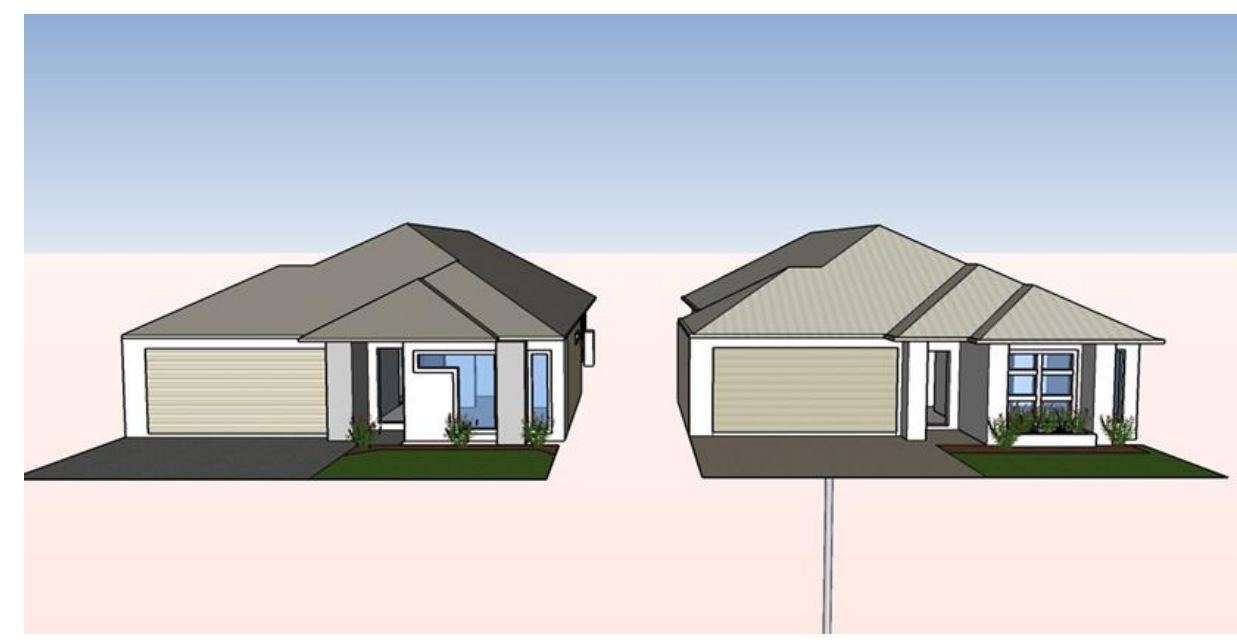

Figure 1: An illustration of two houses that are nearly identical. Left: ASHP, right: GSHP

Both houses were constructed on a $375 \mathrm{~m}^{2}$ plot of land with a built-up space of roughly $270 \mathrm{~m}^{2}$ and were facing west. They are physically identical and depict a typical Western Australian house. Each home features four bedrooms, two bathrooms, a movie room, a double garage, and a kitchen/living room area. The external walls of the dwellings are made of two bricks with an air gap between them. In the majority of Perth metropolitan residences, this is the construction style. Both the inside and outside of the residences are finished in the same manner. Both homes have Colorbond ${ }^{\circledR}$ steel roofs that are insulated with R4.1 insulation. The ceiling is $10 \mathrm{~mm}$ plasterboard with a $1.5 \mathrm{~kW}$ solar panel system installed. The front of the home has a double lock-up garage and the laundry is behind it. The main bedroom is located at the front of the house. The second and third bedrooms, as well as a second bathroom that separates the fourth bedroom, are located at the back of the home. The movie room is located next to the fourth bedroom.

\subsection{GSHP System Description}

The GSHP system utilises a standing column well (SCW), also known as a doublet system, to access and return groundwater as a heat source for heating and a heat sink for cooling. As shown in Figure 2, the GSHP

Journal homepage: http://teknomekanik.ppj.unp.ac.id

DOI: https://doi.org/10.24036/teknomekanik.v4i2.11272 
system includes a Water Furnace NVK-012, 15 kW GSHP unit, a Caprari CapSub-3 System 2 model 30-65 submersible pump with a nominal power rating of $900 \mathrm{~W}$, and a SCW structure. For this system, a 200-mm diameter borehole was drilled to a depth of 57 meters, with the water table at 34.4 meters [33]. At a depth of 35 meters below ground level, the returned groundwater is reinjected into the aquifer. For heat transmission between bore water and the refrigerant, a concentric tube heat exchanger is utilised.

The capabilities of the systems in both houses varied by $3 \mathrm{~kW}$, with the capacity of the GSHP house being greater. The builder and equipment provider took these decisions, presumably to be cautious because GSHPs were new to the market. Both homes employ centralized all-air systems with their own air handling units (AHUs) and terminal units. AHU fan power is used into COP calculations. This concept sought to decrease water stream short-circuiting while simultaneously lowering drilling expenses. The temperature of the groundwater is relatively steady at $22^{\circ} \mathrm{C}$. Perth's aquifers have typically good water quality for geothermal purposes. The Yarragadee aquifer has a wide variety of salinities, from fresh to brackish. As you travel deeper, the salinity level rises. It is about $1 \mathrm{~g} / \mathrm{L}$ up to $1100 \mathrm{~m}$ below ground level, and $30 \mathrm{~g} / \mathrm{L}$ at $1300 \mathrm{~m}$ below ground level [31]. The water quality at the research site is excellent, with a salinity of $0.25 \mathrm{~g} / \mathrm{L}$, low risk of iron staining, and no risk of acid sulphate class [18]. As a consequence, at the specified location, an open-loop GSHP system is appropriate.

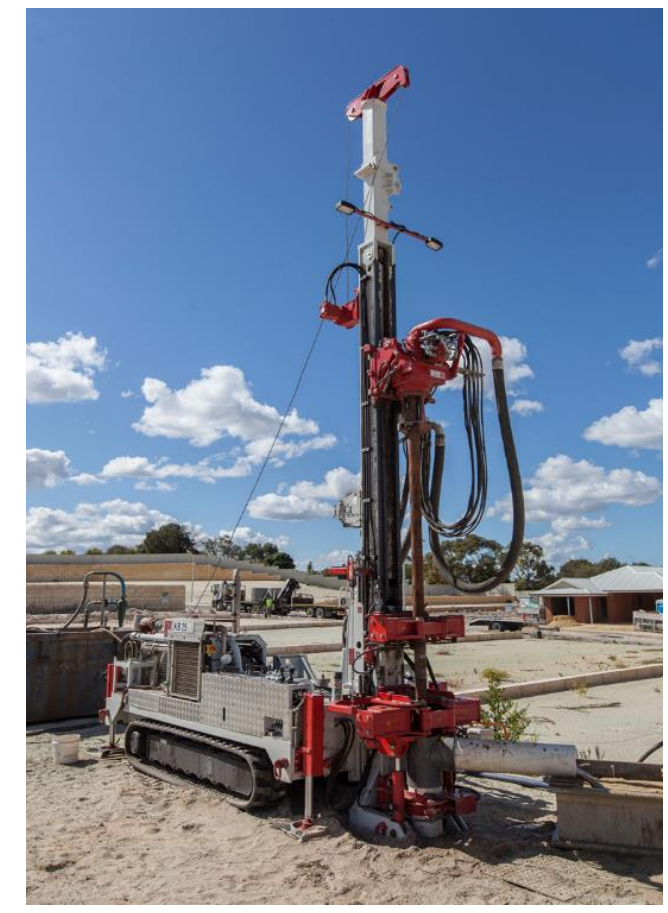

Figure 2: The GSHP underground water source arrangement using a doublet system

\subsection{ASHP System Description}

A Samsung Duct S AC120HBHFKH/SA indoor unit and an inverter-based Samsung Duct S AC120HCAFKH/SA outdoor unit with a refrigerant charge of $2.9 \mathrm{~kg}$ of R410A and a standard cooling capability of $12 \mathrm{~kW}$ are installed in the ASHP home. This ASHP system is a split ducted unit, which may be found in many Western Australian houses.

\section{INSTRUMENTATION}

The Onset HOBO RX3000 Remote monitoring station was utilised as the data logger. The devices employed a cloud backdrop that allowed data to be accessed via the HOBOlink portal; data was captured every 15 minutes to accommodate for sensor response time. The sensors in both residences were calibrated by Delta Building Automation. The data logged from the HOBO RX3000 remote monitoring station was reviewed to ensure that the readings were correct.

Journal homepage: http://teknomekanik.ppj.unp.ac.id

DOI: https://doi.org/10.24036/teknomekanik.v4i2.11272 
FCU inlet and outlet temperatures, ambient, living room temperatures in both dwellings, and groundwater inlet and outlet temperatures were all measured at 15-minute intervals for the GSHP. Outdoor temperature sensors were shielded with a solar radiation barrier (Onset RS3B).

\section{ANALYSIS}

After the downloaded data was filtered, only steady-state data for at least 45 minutes was used for comparative studies. Data was additionally removed when the FCU inlet/outlet temperature drifted by more than $1{ }^{\circ} \mathrm{C}$ from the previous value or when the estimated FCU inlet/outlet absolute humidity changed by more than $1 \mathrm{~g} / \mathrm{kg}$ of dry air to avoid including data during unstable operation. The average power factor of the variable-frequency-drive based GSHP was 0.79, whereas the power factor of the inverter-based ASHP system was 1.00. (both measured with Fluke 1738).

\subsection{Heating and Cooling Capacities}

The ASHRAE psychrometric calculation approach [34] was used to compute the specific volume, absolute humidity, specific enthalpy, and specific heat of moist air. Wangara, Perth meteorological data was utilized to determine ambient conditions (atmospheric pressure, temperature and relative humidity). By numerically integrating instantaneous data over 45 minutes, the average heating and cooling capacities were calculated:

$$
\begin{gathered}
Q_{h}=\frac{1}{45 \min } \int_{0}^{45 \min }\left(\frac{q}{v}\right) c_{p}\left(t_{2}-t_{1}\right) d \tau \\
Q_{c}=\frac{1}{45 \min } \int_{0}^{45 \min }\left(\frac{q}{v}\right)\left[\left(h_{1}-h_{2}\right)-\left(W_{1}-W_{2}\right) h_{w 2}\right] d \tau
\end{gathered}
$$

The heating and cooling capacity' uncertainties were estimated using the technique provided by NIST [35] and determined to be $7.5 \%$ for heating and $8.2 \%$ for cooling, respectively. Electrical power input was also handled in a similar manner.

\section{2. $C O P s$}

The coefficients of performance (COPs) are then calculated as follows:

$$
\begin{aligned}
C O P_{h} & =\frac{Q_{h}}{\frac{1}{45 \mathrm{~min}} \int_{0}^{45 \min } P_{i n} d \tau} \\
C O P_{c} & =\frac{Q_{c}}{\frac{1}{45 \min } \int_{0}^{45 \min } P_{i n} d \tau}
\end{aligned}
$$

Because electrical power measurement has a modest margin of error, the total relative uncertainty in COPs can be anticipated to be similar to that of heating and cooling capabilities.

\section{RESULTS AND DISCUSSION}

Over the period of two years, Figure 3 illustrates the heating and cooling capacities of both systems. Despite the fact that the temperature settings and housing are same in both homes, the systems' capabilities are drastically different. This can be attributed to actual heating and cooling loads caused by resident usage patterns, which are determined by the number of people living in the home, the number of zones that are actually used, and interior sources such as refrigerators, microwaves, gas stoves, television sets, computers, and so on. The dispersion in the data is due to diurnal/seasonal variations in cooling/heating demands on the systems. Residents in the ASHP home appear to be more conservative in their settings than those in the GSHP house. The difference in the nature of heating/cooling demands between GSHP and ASHP households is

Journal homepage: http://teknomekanik.ppj.unp.ac.id

DOI: https://doi.org/10.24036/teknomekanik.v4i2.11272 
something to notice. Figure 3 depicts the qualitative behavior of the two systems in relation to the surrounding circumstances. The ASHP home follows the ambient temperature with a modest trend. As a result, a preferable criterion for evaluation will be the $C O P$, which will be discussed later.

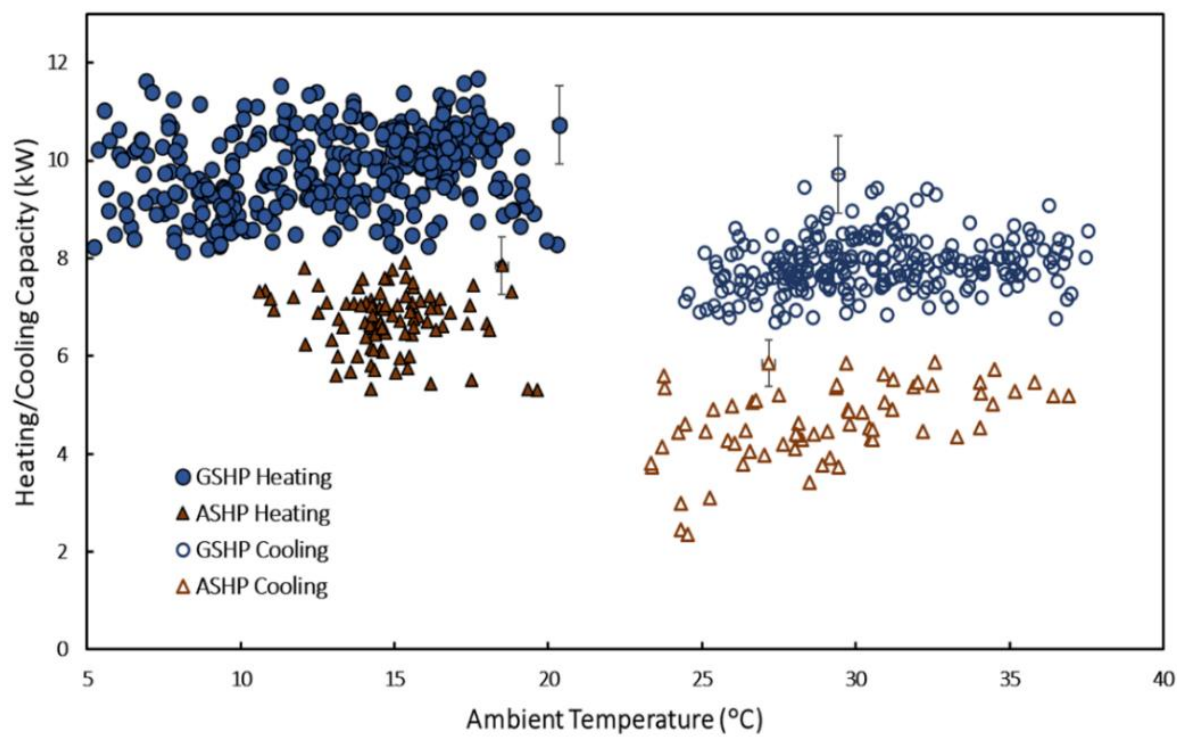

Figure 3: GSHP and ASHP heating and cooling capacities at varied ambient temperatures.

Figure 4 shows the COPs of both heating and cooling systems throughout the course of a two-year testing period. There is substantial dispersion in the data since each data point is associated to diurnal and seasonal external factors such as sun shine, cloud cover, variations in surface conditions of surfaces, ambient air velocity, and so on. The usual error bars associated with the data are presented for one point in each case. As previously noted, ambient temperature has little effect on the COP of GSHP, fluctuating only by around 0.8 between heating and cooling, which is near to the theoretical limit of 1 .

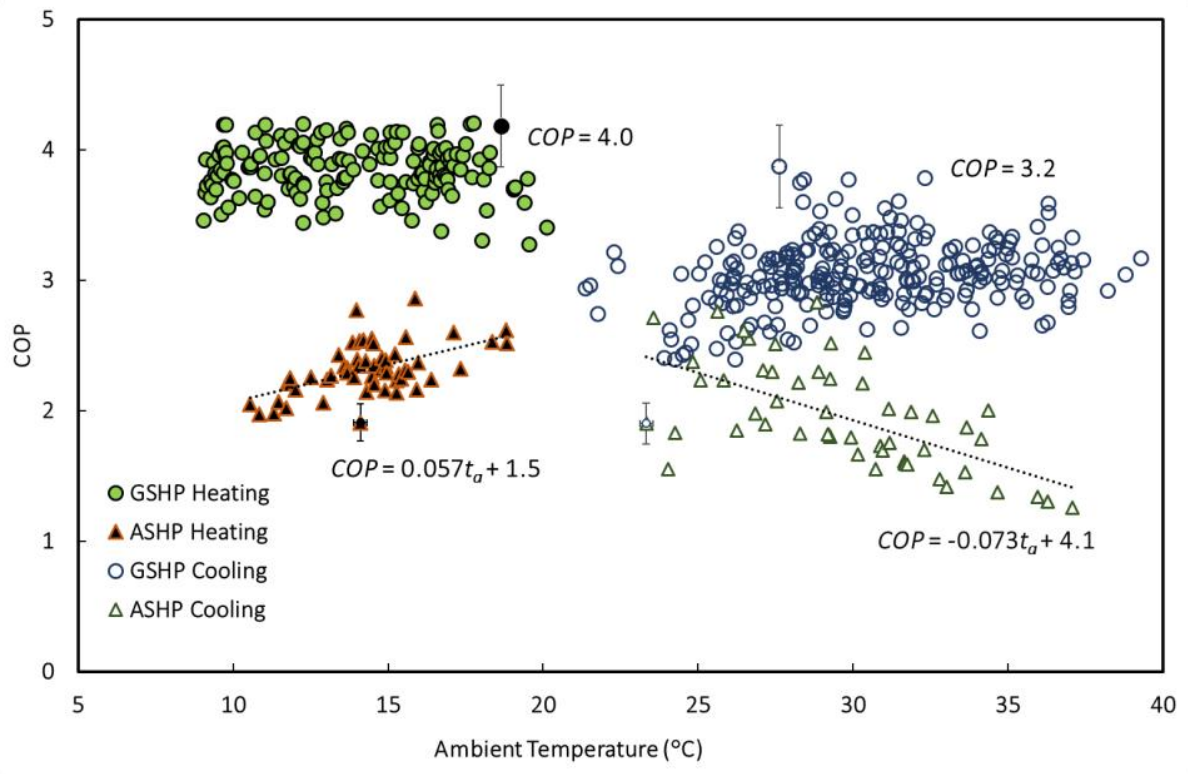

Figure 4: A COP comparison of GSHP and ASHP at various ambient temperatures

On the other hand, when it comes to ASHP, there is a clear tendency of increasing with ambient temperature during heating and decreasing with ambient temperature during cooling. Only when the outside temperature is near to the groundwater temperature does the COP of the ASHP home match that of the GSHP.

Journal homepage: http://teknomekanik.ppj.unp.ac.id

DOI: https://doi.org/10.24036/teknomekanik.v4i2.11272 
In general, GSHP systems are projected to have higher COPs than ASHP systems throughout the course of a year's operation, resulting in decreased power consumption and associated indirect emissions. This is especially true in Perth, where the summers are extremely hot and the winters are quite cold. The COP's trend lines are also displayed in Figure 4.

The COP of the GSHP house has risen significantly for both heating and cooling, as shown in Figure 4. Based on this, it is anticipated that the GSHP home would have saved around AUD $\$ 1050$ per year in energy expenditures if it had not switched to ASHP. This equates to $3646 \mathrm{kWh}$ of power at a cost of $28.8 \mathrm{cents} / \mathrm{kWh}$. Based on $0.7 \mathrm{~kg}$ of $\mathrm{CO}_{2} / \mathrm{kWh}$ for Perth [36], the environmental advantages will be around $2.5 \mathrm{t}$ of $\mathrm{CO}_{2}$ emission reduction. Based on $7 \mathrm{t} / \mathrm{dwelling} /$ year [37], this represents a $35 \%$ decrease in greenhouse gas emissions. It is indeed simple to calculate how much of a difference GSHP would make if every home in Perth had a borewell for reticulation. Installing a GSHP in an existing home with a borewell might potentially provide substantial financial and environmental benefits. In addition, the influence of groundwater quality on the heat exchanger and pipelines in GSHP systems must be evaluated over time. However, the water quality in the current research was sufficient to avoid derating during its operation.

\section{CONCLUSIONS}

The purpose of this study was to compare the performance of an open-loop GSHP system to a traditional ASHP in the residential sector of Perth, Western Australia. Each category was only compared with one dwelling. When utilized for both heating and cooling, the GSHP system performed significantly better than the ASHP. The GSHP system has an average COP of 3.2 for cooling, which is almost independent of external temperatures. The COP of the ASHP system, on the other hand, varied from 1.4 to 2.9, depending on outside temperatures. Similarly, the COP of the GSHP system stayed virtually constant at 4.0 for heating, but the COP of the ASHP system varied from 2.0 to 3.0 depending on outside conditions.

\section{ACKNOWLEDGEMENTS}

The University of Western Australia, DevelopmentWA, GeoExchange, Carbonomics, ABN Group, and The Vive at Craigie collaborated on this study. The authors would like to thank The Australian Institute of Refrigeration, Air Conditioning and Heating (AIRAH) for their advice, QED Environmental Services for assisting with the leak tests for the houses, and Adrian Middleton of Delta Automation for his support and assistance in checking the sensors and calibrating the air flow rates.

\section{REFERENCES}

[1] "https://www.aer.gov.au/wholesale-markets/wholesale-statistics/national-electricity-marketelectricity-consumption." (accessed Feb. 14, 2021).

[2] Department of Industry, Science, Energy and Resources, Australian Energy Update 2020, September 2020, Australian Energy Statistics, ISSN (Online): 2203-8337

[3] U. Lucia, M. Simonetti, G. Chiesa, and G. Grisolia, "Ground-source pump system for heating and cooling: Review and thermodynamic approach," Renew. Sustain. Energy Rev., vol. 70, no. November 2016, pp. 867-874, 2017, doi: 10.1016/j.rser.2016.11.268.

[4] J. Egg and B. C. Howard, "Geothermal HVAC: green heating and cooling." McGraw-Hill, New York, 2011, [Online]. Available: http://accessengineeringlibrsary.com/browse/geothermal-hvacgreen-heating-and-cooling.

[5] S. S. Naicker and S. J. Rees, "Performance analysis of a large geothermal heating and cooling system," Renew. Energy, vol. 122, no. February, pp. 429-442, 2018, doi: 10.1016/j.renene.2018.01.099.

[6] J. W. Lund, D. H. Freeston, and T. L. Boyd, "Direct utilization of geothermal energy 2010 worldwide review," Geothermics, vol. 40, no. 3, pp. 159-180, 2011, doi: 10.1016/j.geothermics.2011.07.004.

[7] D. Lovell et al., "Thermal performance prediction of outdoor swimming pools," Build. Environ, vol. 160, no. May, 2019, doi: 10.1016/j.buildenv.2019.106167.

[8] A. Christ, B. Rahimi, K. Regenauer-Lieb, and H. T. Chua, "Techno-economic analysis of geothermal desalination using Hot Sedimentary Aquifers: A pre-feasibility study for Western Australia," Desalination, vol. 404, pp. 167-181, 2017, doi: 10.1016/j.desal.2016.11.009.

Journal homepage: http://teknomekanik.ppj.unp.ac.id

DOI: https://doi.org/10.24036/teknomekanik.v4i2.11272 
[9] "https://industry.gov.au/Office-of-the-Chief Economist/Publications/Documents/GA21797.pdf." (accessed Feb. 14, 2021).

[10] Q. Lu, G. A. Narsilio, G. R. Aditya, and I. W. Johnston, "Economic analysis of vertical ground source heat pump systems in Melbourne," Energy, vol. 125, pp. 107-117, 2017, doi: 10.1016/j.energy.2017.02.082.

[11] Australian Renewable Energy Agency, "Renewable geothermal heat pumps trialled at Blacktown greenfield estate," ARENA media, Australian Government, 2019. https://arena.gov.au/assets/2019/01/ARENA-Media-Release_Climatc-KIC-to-trial-geothermalpumps-at-Fairwater-residential-estate-in-Blacktown-250119x.pdf (accessed Jan. 20, 2021).

[12] P. Hannam, "Suburban test-bed for geothermal heating and cooling," The Sydney Morning Herald. Fairfax Media Publications Pty Limited, p. 8, 2017, [Online]. Available: https://www.smh.com.au/environment/sustainability/geothermal-a-technology-that-blows-hot-andcold-in-sydneys-booming-west-20170410-gvherz.html.

[13] A. L. Kirkby, "The Ground Source Heat Pump at Geoscience Australia," Preview, vol. 2011, no. 153, pp. 29-30, 2011, doi: 10.1071/pvv2011n153p29.

[14] Y. Lu, K. Hooman, A. D. Atrens, and H. Russell, “An experimental facility to validate ground source heat pump optimisation models for the australian climate," Energies, vol. 10, no. 1, 2017, doi: 10.3390/en10010138.

[15] J. Luo, J. Rohn, W. Xiang, D. Bertermann, and P. Blum, “A review of ground investigations for ground source heat pump (GSHP) systems,” Energy Build., vol. 117, pp. 160-175, 2016, doi: 10.1016/j.enbuild.2016.02.038.

[16] A. Michopoulos, T. Zachariadis, and N. Kyriakis, "Operation characteristics and experience of a ground source heat pump system with a vertical ground heat exchanger,” Energy, vol. 51, pp. 349357, 2013, doi: 10.1016/j.energy.2012.11.042.

[17] D. Vanhoudt, J. Desmedt, J. Van Bael, N. Robeyn, and H. Hoes, “An aquifer thermal storage system in a Belgian hospital: Long-term experimental evaluation of energy and cost savings," Energy Build., vol. 43, no. 12, pp. 3657-3665, 2011, doi: 10.1016/j.enbuild.2011.09.040.

[18] E. Kim, J. Lee, Y. Jeong, Y. Hwang, S. Lee, and N. Park, "Performance evaluation under the actual operating condition of a vertical ground source heat pump system in a school building," Energy Build., vol. 50, pp. 1-6, 2012, doi: 10.1016/j.enbuild.2012.02.006.

[19] S. L., X. Liu, and J. Spitler, "Performance of the HVAC Systems at the ASHRAE Headquarters Building, Part 1: Measured Energy Usage,” ASHRAE J., Sep. 2014.

[20] Y. Lyne, H. Paksoy, and M. Farid, "Laboratory investigation on the use of thermally enhanced phase change material to improve the performance of borehole heat exchangers for ground source heat pumps," Int. J. Energy Res., vol. 43, no. 9, pp. 4148-4156, 2019, doi: 10.1002/er.4522.

[21] J. Molavi and J. McDaniel, "A Review of the Benefits of Geothermal Heat Pump Systems in Retail Buildings,” Procedia Eng., vol. 145, pp. 1135-1143, 2016, doi: 10.1016/j.proeng.2016.04.147.

[22] S. J. Self, B. V. Reddy, and M. A. Rosen, "Geothermal heat pump systems: Status review and comparison with other heating options," Appl. Energy, vol. 101, pp. 341-348, 2013, doi: 10.1016/j.apenergy.2012.01.048.

[23] J. Song et al., "Heating performance of a ground source heat pump system installed in a school building," Sci. China Technol. Sci., vol. 53, no. 1, pp. 80-84, 2010, doi: 10.1007/s11431-009-04228.

[24] A. Michopoulos, V. Voulgari, A. Tsikaloudaki, and T. Zachariadis, "Evaluation of ground source heat pump systems for residential buildings in warm Mediterranean regions: the example of Cyprus," Energy Effic., vol. 9, no. 6, pp. 1421-1436, 2016, doi: 10.1007/s12053-016-9431-1.

[25] M. R. H. Abdel-Salam, A. Zaidi, and M. Cable, "Field study of heating performance of three groundsource heat pumps in Canadian single-family houses,” Energy Build., p. 110959, 2021, doi: https://doi.org/10.1016/j.enbuild.2021.110959.

[26] J.-H. Lim, “Application of geothermal heat pumps in a renovated campus building," Int. J. Energy Res., vol. 34, no. 5, pp. 445-453, 2010, doi: https://doi.org/10.1002/er.1648. 
[27] P. F. Healy and V. I. Ugursal, "Performance and economic feasibility of ground source heat pumps in cold climate," Int. J. Energy Res., vol. 21, no. 10, pp. 857-870, 1997, doi: https://doi.org/10.1002/(SICI)1099-114X(199708)21:10<857::AID-ER279>3.0.CO;2-1.

[28] A. Hepbasli, "Performance evaluation of a vertical ground-source heat pump system in Izmir, Turkey," International Journal of Energy Research, vol. 26, no. 13. pp. 1121-1139, 2002, doi: 10.1002/er.839.

[29] P. Christodoulidesa, L. Arestib and G. Florides, "Air-conditioning of a typical house in moderate climates with Ground Source Heat Pumps and cost comparison with Air Source Heat Pumps,” Appl. Thermal Eng., vol. 158, 113772, 2019, doi.org:10.1016/ j.applthermaleng.2019.113772.

[30] S. Maddah, M. Goodarzi, and M. R. Safaei, "Comparative study of the performance of air and geothermal sources of heat pumps cycle operating with various refrigerants and vapor injection," Alexandria Eng. J., vol. 59, no. 6, pp. 4037-4047, 2020, doi: 10.1016/j.aej.2020.07.009.

[31] https://www.water.wa.gov.au/urban-water/bores (accessed on 4 May 2021)

[32] https://www.bbc.com/future/article/20201006-india-why-bangalore-is-digging-a-million-wells (accessed on 11 May 2021).

[33] Aprianti T, Tan E, Diu C, et al. A comparison of ground and air source heat pump performance for domestic applications: A case study in Perth, Australia. Int J Energy Res. 2021;1-14. https://doi.org/10.1002/er.7133

[34] ASHRAE Handbook of Fundamentals, vol. 30329, no. 404. Atlanta: American Society of Heating, Refrigerating and Air-Conditioning Engineers, Inc., 2009.

[35] B. N. Taylor and .C E. Kuyatt, "Guidelines for Evaluating and Expressingthe Uncertainty of NIST Measurement Results” NIST Technical Note 1297 (1994), Physics Laboratory, National Institute of Standards and Technology, Gaithersburg, MD 20899-0001.

[36] https://www.environment.gov.au/system/files/resources/5a169bfb-f417-4b00-9b706ba328ea8671/files/national-greenhouse-accounts-factors-july-2017.pdf (accessed 14 May 2021).

[37] https://www.yourhome.gov.au/energy\#: :text=The\%20average $\% 20$ Australian $\% 20$ home $\% 20$ is, greenhouse $\% 20$ gas $\% 20$ emissions $\% 20$ each\%20year (accessed on 11 May 2021).

\section{NOMENCLATURE}

$\begin{array}{ll}c & \text { velocity }(\mathrm{m} / \mathrm{s}) \\ c_{p} & \text { specific heat capacity of moist air }\left(\mathrm{kJ} / \mathrm{kg}{ }^{\circ} \mathrm{C}\right) \\ h & \text { specific enthalpy }(\mathrm{kJ} / \mathrm{kg}) \\ P & \text { power }(\mathrm{kW}) \\ q & \text { volumetric flow rate }(1 / \mathrm{s}) \\ Q & \text { cooling } / \text { heating capacity }(\mathrm{kW}) \\ t & \text { temperature }\left({ }^{\circ} \mathrm{C}\right) \\ v & \text { specific volume of moist air }\left(\mathrm{m}^{3} / \mathrm{kg}\right) \\ W & \text { humidity ratio }(\mathrm{kg} / \mathrm{kg} \text { of } \text { dry air }) \\ \text { Greek letters } & \\ \phi & \text { relative humidity } \\ \tau & \text { time (min) } \\ \text { Subscripts } & \\ 1 & \text { inlet of FCU } \\ 2 & \text { outlet of FCU } \\ a & \text { ambient } \\ c & \text { cooling } \\ h & \text { heating } \\ \text { in } & \text { input } \\ w 2 & \text { saturated liquid water }\end{array}$

Journal homepage: http://teknomekanik.ppj.unp.ac.id

DOI: https://doi.org/10.24036/teknomekanik.v4i2.11272 